\title{
An Economic Efficiency Approach to Reforming Corporate Governance: The Case of Multiple Stakeholder Boards
}

\author{
Say H. GOO*
}

Faculty of Law, The University of Hong Kong

\begin{abstract}
This paper points out the problems of the current law on directors' duties that forces directors to ignore stakeholder interests, with the unintended consequences of misallocation of resources and the weaknesses of a traditional legal approach to law reform, and uses multiple stakeholder boards as an example to demonstrate how an economic efficiency approach to law reform, adopting economic principles, could avoid some of the unintended consequences of a legal approach to law reform and help design better rules that promote allocative efficiency for the benefit of society as a whole. It argues that international organizations should take the lead in promoting the use of stakeholder directors in the board of directors of multinational corporations that have a history of corporate abuses for corporate decisions that have an impact on all stakeholders.
\end{abstract}

Keywords: allocative efficiency, economic principles, free market, stakeholder interests, stakeholder board

\section{THESIS OF THIS PAPER}

The importance of corporate governance in the modern business world and society cannot be over-emphasized. Whilst the link between good corporate governance and good corporate performance continues to be challenged by some scholars, it is fairly well accepted now that good corporate governance is generally important for corporations, investors, and society affected by the operation of the corporations. As there are still corporate governance problems around the world, how best to reform corporate governance continues to be a matter of great concern.

In many countries, law reform in the past has often been influenced more by what is right or wrong (normative enquiry) or what is fair or unfair (justice consideration, in particular, distributive justice), but less influenced by economic efficiency (law and economic analysis or economic consideration) of the proposed rules, especially outside North America, such as the UK and Hong Kong (HK). Proposals for law reform are often drafted to solve the problems or mischief to be resolved based on logic, fairness, legality, and/or other social,

* Professor of Law, Faculty of Law, The University of Hong Kong. This paper is based on the author's earlier research and paper: Goo \& Klingler (2014). The author would like to thank the Hong Kong Research Grant Council for a Theme-Based Research Scheme grant for the project "Enhancing HK as an International Financial Centre" that enables the author to further his research for this paper. Correspondence to Say H. Goo, The University of Hong Kong, Faculty of Law, Pokfulam Road, Hong Kong. E-mail address: shgoo@hku.hk. 
political, and practical considerations. ${ }^{1}$ Although economic considerations may sometimes be taken into account or be implicit, ${ }^{2}$ they do not drive the direction of the reform. This sometimes leads to the adoption of the wrong rules, with unintended consequences. My thesis is that we should consider the economic principles of the free market in law reform, especially in the area of corporate law and corporate governance, and more generally in the area of economic law (which includes corporate law, financial law, commercial law, business law, and tax law, etc.), and adopt rules that would facilitate the operation of the free market, remove factors that have caused market failures, and promote allocative efficiency. ${ }^{3}$

As will be explained in this paper, it is not necessary ${ }^{4}$ to adopt a strict cost-benefit analysis or quantitative or empirical approach that many law and economic proponents have come to embrace in the past. This is because it is often difficult to accurately quantify the cost and benefit of a proposed new rule even with empirical data or modelling. Furthermore, even if the cost of the proposed rules or measures to be adopted would initially outweigh the benefit, the rules may still be necessary to maintain market confidence and integrity. Therefore, we should instead analyze whether the rule to be adopted would remove the obstacles to the smooth operation of the free market rather than whether the cost outweighs the benefit. ${ }^{5}$ This paper will focus on the discussion of the current rules on the functions, duty, and composition of the board of directors in a corporation to demonstrate the limitation of the approach to law reform hitherto and how an economic approach to law reform as explained above could help design better rules, although the thesis above can be applied generally to other areas of economic law, such as whether companies with weighted voting rights or a dual class-share structure should be allowed to list on an exchange, ${ }^{6}$ whether property tax or extra stamp duty should be levied to cool a property market, ${ }^{7}$ etc.

However, rules that allow the free market to function efficiently can also lead to certain sections of society deprived of the resources allocated under the free-market system; for example, a completely free property market without restrictions on sales can cause property prices to be unaffordable for many local residents. Where the resources are basic and fundamental to every individual's need in society (e.g. basic food, necessity, and housing), other measures need to be taken by the state to provide a safety net for these sections of society so that they can have access to these resources (the social justice consideration). This paper therefore also accepts that, in such a situation, other considerations need to be taken into account as well. The examination of what situation would require social justice

1. See Posner (1974-75), p. 768, who put it in a different language.

2. Ibid., p. 764.

3. The idea that one's understanding in fields such as anti-trust, regulated industries, consumer and environmental protection, corporate finance, and regulation of international trade is seriously incomplete if he does not embrace the relevant economic concepts has been long acknowledged. See ibid., p. 779.

4. It has been pointed out that "[w]hile economics does lend itself to mathematical exposition, mathematical skill is not the heart of economic understanding. The heart of the subject, as in law, is a knack for looking at things in a certain way," ibid., p. 780.

5. Posner has suggested that we should think like economists as well as like lawyers, and be sensitive to the economic dimensions of problems, and familiar in a broad way with how the economist analyzes a legal issue or institution, and be able to bring the fundamental principles of economics to bear on a variety of questions arising in the practice of law; ibid., p. 780. He proposed the teaching of an introductory course in economic theory designed for law students that stresses fundamental economic principles (not techniques) and their application to specific problems of law and public policy; ibid., p. 780.

6. See Goo (2015).

7. See Goo (2017). 
consideration - the detailed criteria involved-is, however, beyond the scope of this paper. Another related issue to law reform, namely whether such a rule change should be done through self-regulation or government regulation, as they both have advantages and disadvantages depending on the institutional arrangements and culture (i.e. the consideration of cost of regulation and enforcement), is also beyond the scope of this paper.

On the rules relating to the board of directors, my conclusions are:

1. the existing common-law rule that the board of directors must act in the best interest of the company that is often interpreted by the court ${ }^{8}$ and business people ${ }^{9}$ to mean the interests of the shareholders has caused the unintended consequence that other stakeholders' interests are ignored by the board, resulting in many other serious consequences for society, such as human rights abuses and environmental degradation by corporations;

2. the common-law rule that directors owe the above-mentioned duty to the company that is often interpreted to mean the shareholders make it impossible for directors to act in the interest of other stakeholders or risk being sued by shareholders (an unintended consequence);

3. the combination of (1) and (2) above results in directors being able to make decisions that would externalize the costs of company's production, causing resources to be allocated inefficiently (to society) by the corporation;

4. an economic approach to law reform would suggest that proposed rules should be designed to force corporation to internalize the costs; thus, there are already many other laws and regulations (such as environmental laws, labour laws, etc.) that are designed to have that effect, but there are often gaps in the law and enforcement problems relating to such laws. Corporate law rules should be designed to enable stakeholder interests to be taken into account by the board of directors. This would force the corporation to internalize the costs of production at board level, which is a more direct solution than relying on environmental and other laws;

5. with this economic approach to law reform, a number of new rules can be considered: (1) corporations can be required to appoint directors representing stakeholders to the board of directors; (2) each stakeholder director will owe a duty to the stakeholders he represents, subject to the overarching duty of good faith to act in the interest of the company (which should mean all stakeholders including shareholders).

\section{ECONOMIC APPROACH TO LAW REFORM}

\subsection{The Methodology Explained}

In contrast to the mainstream law and economic literature, this thesis adopts an approach based on economic principles of the free market, not the orthodox cost-benefit analysis or

8. For example, see Re Smith \& Fawcett Ltd [1942] Ch. 304; Boyle \& Birds (1995), p. 452, suggests that "interests of the company" means the interests of the company as a commercial entity to be judged in most cases by reference to the interests of present and future shareholders alone. In Greenhalgh v. Arderne Cinemas Ltd [1951] Ch. 286, 291, Evershed M.R. said that it means the corporators as a general body; see also Farrar (1991), p. 384.

9. See e.g. Friedman (1970). 
quantitative or empirical data. The economic principles explain that a free market is the most efficient way of allocating resources, provided certain conditions exist: (1) buyers and sellers act rationally and (2) have full information regarding the transactions, (3) exchanges are costless, (4) buyers and sellers carry out obligations as agreed, and (5) buyers and sellers can enter and leave the market freely. ${ }^{10}$

However, in practice, there are often impairments to free-market conditions: (1) parties do not always act rationally, (2) there is often information asymmetry, (3) cost is often unavoidable due to the information asymmetry and opportunistic behaviour: there is the cost of dealing (fees paid to intermediaries), agency costs (cost of loss and cost paid to reduce agency cost and to monitor performance), social costs (loss suffered when contracts are not fulfilled), opportunity cost, ${ }^{11}$ and (4) not all transactions are performed as agreed. Thus, regulation is required to correct these market failures.

In my view, the role of law and regulations is, therefore, to facilitate a free market and to correct market failures. This will lead to allocative efficiency and wealth creation, which are good for the corporations and society. Furthermore, corporations exist because of market failure; they exist to reduce transaction and information-gathering costs. ${ }^{12}$ Thus, we should design corporate law and regulation concerning corporate governance that will facilitate a free market and correct market failure.

Thus, where the market failure manifests itself in the form of increased agency costs, it is not necessary for the government to prohibit the transactions or behaviour in question. The government could leave it to the parties to resolve disputes concerning transactions or behaviour according to market principles. ${ }^{13}$ For example, in the recent debate on whether an exchange should allow companies with a dual class-share structure or weighted voting rights share-holding structure to be listed on the exchange, currently many countries prohibit such a listing (e.g. HK, the UK, mainland China). This prohibition does not reflect market need and does not facilitate the efficient allocation of resources through the exchanges. There is demand from innovative enterprises with dual class-share structures to raise funds for their operation through exchanges. There is a supply of such funds from investors. We should consult the economic principles of a free market and resource allocation in considering whether the exchange should be allowed to provide a platform for such a market (i.e. whether such a listing should be allowed as in the US) and, if so, what rules should be adopted to safeguard the operation of the market. As the fear for a dual class-share structure is that founding shareholders with superior voting rights may engage in private benefit extraction that increases the agency costs to the detriment of other shareholders, ${ }^{14}$ rules on shareholder protection should be designed to reduce this type of agency cost, rather than prohibiting the listing of firms with a dual class-share structure all together.

Similarly, on independent directors, currently many countries have adopted the independent director system to reduce agency costs. This is an example of a measure that seeks to facilitate a free market, as it is meant to reduce agency costs. However, it is not effective in

\footnotetext{
10. Cheffins (1997), p. 6.

11. See Coase (1960).

12. See Coase (1937).

13. See Coase, supra note 11.

14. See e.g. Ashton (2012).
} 
many countries. We should consider, guided by the economic principles of the free market, what other changes can be made to the independent director system to make it effective in reducing agency costs. This paper will use stakeholder voices as an example to explain the economic approach to law reform. Currently, the law in many countries does not allow direct reflection of stakeholder voices in the decision-making process of a corporation. This frustrates the efficient allocation of resources through the market, as the costs of a company's

operation and production can be externalized by the company. ${ }^{15}$ This paper will consult economic principles to consider the adoption of stakeholder boards as a measure to internalize such costs.

\subsection{Originality of the Methodology}

The methodology, namely an approach to law reform guided by the economic principles of a free market, is I believe quite original, particularly in the UK and HK. Like the current law and economic approach, it seeks to apply economic theory (particularly microeconomic theory) to the analysis of law. However, it is different from the current law and economics approach, which is cost-benefit analysis based on quantitative empirical modelling. It is also different from traditional legal analysis, which is based on what is right or wrong, or fair or unfair (legal analysis). The former is often too technical and it is difficult to accurately assess the cost and benefit of each rule, which leads to unintended consequences (or hidden costs) and may also ignore the integrity of the market and social justice. The latter leads to the prohibition or adoption of rules that go against the free market (or produce unintended consequences) and are bad for economic development or lead to a black market (i.e. law in a book is different from law in action). My approach is informed both by market and economic principles, and the importance of market integrity and social justice.

\subsection{Importance of Economic Approach to Law Reform}

The importance of an economic approach to law reform has been well recognized for a long time now. ${ }^{16}$ This approach will help build a better market economy, and fairer and more stable society. On weighted voting rights, returning to the example I gave earlier, the approach will lead to a more versatile and developed capital market to meet the demand and needs of the economic development of a developing country. On independent director and stakeholder voices, the approach will improve the effectiveness of independent directors, reduce agency costs, and enhance stakeholder voices as represented by stakeholder directors at the boardroom, which will lead to better allocation of resources by companies and society as a whole and a happier and healthier society. Indeed, the use of this approach is not restricted to the three areas mentioned above, but can be applied generally in many other areas and fields of law.

This approach to law reform would be particularly valuable to mainland China, which is currently the second largest economy in the world, as it tries to further develop its socialist market economy. Like HK, the Shenzhen Stock Exchange and Shanghai Stock Exchange do not allow firms with a dual class structure to be listed. Whilst employees have some representation on a firm's Board of Supervisors in China, they do not have the same degree of power as employees in a German firm, and yet a firm in a socialist market economy,

15. See Parkinson (1993), pp. 310-11; Goo \& Klingler (2014), p. 192.

16. See Posner, supra note 1, p. 764 and literatures cited therein. 
especially a state-owned enterprise (SOE), must have regard to other stakeholders' interests. Mainland China has also adopted an independent director system that, however, is not effective and overlaps somewhat with the supervisory board. This approach can be of reference value for mainland China to resolve these problems.

\subsection{Building Blocks}

This paper will use the example above, namely stakeholders' interests in the board, to explain how the current law is against economic principles and how economic principles could help design better rules. It will draw on the economic principles that a free market will lead to allocative efficiency, and the conditions necessary for the free market to function efficiently. It will then identify the deficiency in the free-market conditions that leads to market failure, namely the lack of stakeholder voices in a firm that leads to certain costs of production being externalized.

\section{CURRENT LAW}

\subsection{Rule on Directors' Duty to Act in the Interests of the Company}

Under common law, a director owes fiduciary duty to act in the interest of the company. ${ }^{17}$ Although there was some uncertainty on whether "company" refers to present shareholders or also includes future shareholders, ${ }^{18}$ it is clear that it is generally understood by judges and others to mean shareholders, not other stakeholders. Thus, directors owe a duty to maximize profits for the shareholders. This is against the original idea of a corporation. As Henry Carter Adam pointed out:

Corporation originally were regarded as agencies of the state. They were created for the purpose of enabling the public to realize some social or national end without involving the necessity of direct governmental administration. They were in reality arms of the state, and in order to secure efficient management, a local or private interest was created as a privilege or property for corporation. A corporation, therefore, may be defined in the light of history as a body created by law for the purpose of attaining public ends through an appeal to private interest. ${ }^{19}$

In other words, companies must not be allowed to operate solely for the benefit and profit maximization of the shareholders. They must operate for the benefits of the society, namely those involved and affected by their operation.

Although the original idea of a company is to benefit the public, not the private shareholders, this idea is not reflected in case-law. Thus, public interests, namely other stakeholder interests, are excluded from the case-law. As I explained elsewhere, ${ }^{20}$ even the enlightened shareholder value approach under section 172 of the UK Companies Act 2006 does not fully reflect this or allow societal benefit to be achieved. This is because, although directors must take into account stakeholder interests under section 172, they can only do so if it would be "for the benefit of its members [which means shareholders] ${ }^{21}$ as a whole."

17. Re Smith \& Fawcett Ltd; Boyle \& Birds, supra note 8 .

18. Ibid.

19. Nader et al. (1976), p. 63.

20. Goo \& Klingler, supra note 15, p. 194.

21. Words in square brackets added. 
If it would not be for the benefit of the members to consider the interests of stakeholders (e.g. the workers), directors are perfectly entitled to ignore them. For example, if the workers' productivity could be increased by a wage rise and there is a market for the increased volume of goods produced, directors could and should increase pay to workers, as this would increase the profits to shareholders. But if the workers' productivity has reached a peak, or if there is no demand for the increased volume of goods produced, directors cannot and should not pay more to workers, as this will sacrifice the profits available to shareholders, or risk being sued by shareholders for breach of their duties.

The constituency statutes in the US do allow directors to take into account stakeholder interests, ${ }^{22}$ and directors are protected by business judgment rules. However, many directors' executive compensations are tied to the profit of the company, which encourages directors to act only for profit maximization. Constituency statutes are often used (or misused) by directors to protect themselves against hostile takeovers. Thus, again, stakeholder interests are often ignored.

It is not possible to solve this problem by changing the rule to require directors to owe duties to shareholders and other stakeholders. That is because they often have very different interests and it is not possible to please everyone. If a decision of directors does not please everyone, and directors are regarded as having breached the duty they owe to the complaining stakeholders, they will always be liable to some complaining stakeholders and this will deter people from taking up the position of directorship. If, on the other hand, directors are not regarded as having breached the duty owed to the complaining stakeholders because the decision benefits other stakeholders, then directors will always be able to escape liability by claiming that their decision benefits some stakeholders. Both ends of the extreme are not desirable. ${ }^{23}$

\subsection{Rule that Directors' Duties Are Owed to the Company}

Under the case-law, directors' duty to act in the interests of the company is owed to the company, ${ }^{24}$ which means the shareholders. ${ }^{25}$ This means that only shareholders can enforce the duty by derivative suit. ${ }^{26}$ Thus, although under the enlightened shareholder value approach in the UK where directors are required to take into account stakeholders' interests, the duty is owed to the company, meaning shareholders, not stakeholders; stakeholders cannot sue directors by derivative suit for failing to take into account their interests.

\subsection{The Economic Case for Treating "Company" as Meaning "Shareholders"}

There is an economic case for treating the "company" as meaning the "shareholders." As mentioned above, resources are allocated efficiently in a free market, which exists

22. Many states in the US adopted constituency statutes in the 1980s to protect directors when making decisions for the benefit of non-shareholder interests. Together with the business judgment rule, they protect directors who make profit sacrificing socially responsible decisions from shareholder law suits.

23. See Friedman, supra note 9, where he outlined other difficulties a director faces.

24. Percival v. Wright [1902] 2 Ch. 421.

25. See Re Smith \& Fawcett Ltd [1942] Ch. 304.

26. As the duty is owed to the company, only the company can bring an action for breach of duty: Foss v. Harbottle (1843) 2 Hare 461. But, if the company is not suing, shareholders can bring a suit in the name of the company: Edwards $v$. Halliwell [1950] 2 All ER 1064 (CA). Such action is known as a derivative suit. 
when, amongst other things, there is no cost of exchange. However, cost is unavoidable; the best one can do is to keep the cost as low as possible. Shareholder supremacy theory allows costs to be kept as low as possible because, as residual claimants, shareholders have the incentive to do so. Where cost is unavoidable, it must be accurately reflected in the exchange - that is, internalized. When cost is internalized, the free market would weed out the companies that do not know how to keep costs down (i.e. those that misallocate resources) and allow resources in society to be allocated efficiently (achieving societal efficiency). Indeed, as Coase observed, companies exist to reduce transaction costs. ${ }^{27}$ If the cost of running a company and its operation or production is higher than the cost of outsourcing, the company would not survive-the production would be outsourced.

So, if all the costs of production or operation of a company are internalized, and there is free competition in the market for the products or services the company provides, the freemarket competition would ensure societal resources are allocated efficiently in the society. In such circumstances, as Friedman pointed out:

There is one and only one social responsibility of business-to use its resources and engage in activities designed to increase its profits so long as it stays within the rules of the game, which is to say, engages in open and free competition without deception or fraud. ${ }^{28}$

However, as it is often possible for a company to externalize some of the costs of its production or operation, and when there is no free competition, resources are not allocated efficiently under the shareholder supremacy model.

The theory of shareholder supremacy that focuses on profit maximization has enabled many corporations, especially multinational corporations, to be run "efficiently" (in making the most profits possible for themselves, achieving firm-level efficiency) especially when the corporations command some form of oligopoly or monopoly in the market. This firm-level efficiency, however, is often achieved at huge and unquantifiable costs to the state in which the corporation operates when the corporation is able to externalize some of its costs of production (e.g. cost of extra health care suffered by consumers of its products, environmental pollution, social welfare, and subsistence for low-income workers and unemployment benefits). ${ }^{29}$ Where some of the costs are externalized and borne by the state, societal resources cease to be allocated efficiently. As I asked elsewhere, "[i]f these unquantifiable costs are taken into account, can we still be so sure that the profit maximization policy would result in allocative efficiency for the society as a whole (or what may be called societal-level efficiency)?"30

Parkinson argued that " $[\mathrm{w}]$ here producers can externalize costs there is also an efficiency issue, since they will make decisions that involve a misallocation of resources." 31 He further argued that:

[i]f the signals provided by the market are systematically distorted as a result of weak competition and other forms of market failure, then following those signals will not always lead to the most efficient available outcomes. Once this is acknowledged the local and tangible benefits of

27. Coase, supra note 12.

28. See Friedman, supra note 9, emphasis added.

29. Goo \& Klingler, supra note 15.

30. Ibid.

31. Parkinson, supra note 15, p. 311. 
social responsibility begin to look more attractive than the speculative and abstract social gains flowing from a rule of strict profit maximization. ${ }^{32}$

\subsection{The Unintended Consequences}

As explained above, because directors must act in the interests of the company, which means the shareholders, and this duty is owed to the company, which again means the shareholders, directors do not and cannot act in the interests of other stakeholders, or risk being sued by shareholders for failing their duty. This is worsened by the fact that directors' compensations are often tied to the profit of the company. This has profound implications in terms of lack of corporate respect for stakeholder interests. ${ }^{33}$ This, coupled with the fact that companies are able to externalize the cost of production because of gaps in other laws protecting stakeholder interests or lack of enforcement, which I will explain below, leads to the unintended consequence that companies that are not good at making the best or most efficient use of resources can still survive in a competitive market; they are able to make their products competitive by externalizing costs, even though, if all real costs of production had been internalized, the products would have cost a lot more, making them uncompetitive and the companies being forced out of the market in the end. This results in misallocation of resources by the companies.

\subsection{Other Problems with the Law}

An economic approach to law reform outlined above helps us to identify the problem, which is that the current case-law has the unintended consequence of forcing directors to focus on shareholder interests and externalize other costs. The approach also tells us that the right solution is to have rules that would internalize these costs. As I pointed out elsewhere, ${ }^{34}$ there is no shortage of laws and regulations that have the effect of forcing companies to internalize their costs if the laws and regulations are effectively enforced. In addition to law (e.g. criminal law, employment and labour law, health and safety law, consumer law, environmental law, etc.), there are principles, codes, and guidelines that would have the same effect if they are effectively followed. ${ }^{35}$ But costs continue to be externalized because there are always gaps in our laws and regulations, and there are always problems with enforcement of such laws and regulations. Legislation and its amendment take time and effort and may never materialize; it is often done only when a major crisis or disaster has occurred, which obviously comes too late for what has happened. There are difficulties with enforcement, especially in developing countries due to inadequate resources, experience, lack of training

32. Ibid., pp. 310-11.

33. For a documentary film on how profit maximization, as part of capitalism, has destroyed American society, see Capitalism: A Love Story by Michael Moore (2009).

34. Goo \& Klingler, supra note 15, p. 186.

35. E.g. the Universal Declaration of Human Rights; the UN Sub-Commission Norms on Business and Human Rights; the Equator Principles; the European Parliament Code of Conduct; the Extractive Industries Transparency Initiative (EITI); the Geneva Conventions on humanitarian law; the Global Reporting Initiative; the International Labour Organization (ILO) Declaration on Fundamental Principles and Rights at Work; the ILO Tripartite Declaration; the Kimberley Process; the OECD Guidelines; the UN Global Compact; the UN Millennium Development Goals; the UN Principles for Responsible Investment; the Voluntary Principles on Security and Human Rights; guidelines prepared by businesses, governments, judges, NGOs; Environmental, social and governance (ESG) disclosure and reporting through rules of exchanges for listed companies (e.g. The Stock Exchange of Hong Kong Ltd (HKEX)'s listing rules on ESG reporting); international and regional initiatives (e.g. renewed EU strategy 2011-14 for CSR) and guidance for smalland medium-sized enterprises (SMEs) (e.g. CSR Guide for SMEs in Hong Kong); etc. 
and legal infrastructure, corruption of public officials, or lack of independent judiciary. Even in developed countries, some regulations or guidelines are voluntary and therefore not legally enforceable. Some laws are only enforceable by regulators, not shareholders. Even when they are enforceable by shareholders, there is shareholder apathy due to the cost of litigation and other difficulties. Some countries do not have class action. Even where the legal system allows class action, as in the US, it is only available for certain types of law suits; for example, one cannot use class action for breach of directors' duty even in the US, which can only be pursued by shareholders by derivative suits. And there are problems with derivative suits, cost of litigation being one of them.

\section{PROPOSED REFORM}

Thus, it is obvious that laws and regulations alone that seek to regulate a company's operation and its effect on the society are not sufficient to force the company to internalize the cost. Something else is needed.

\subsection{To Require a Stakeholder Director on the Board}

I argued elsewhere that one possibility is to have a governance structure that allows stakeholders to participate in the decision-making process of the company: in other words, having stakeholder directors to represent stakeholder interests on the board of directors-one could have directors representing majority shareholders, minority shareholders, workers, consumers, community, and the environment, respectively. ${ }^{36}$ This will allow stakeholder interests to be factored into the company's decision and internalize the cost directly. This is in line with the current thinking that boards should be more diversified. ${ }^{37}$ A board consisting of stakeholder directors is one type of diversified board.

The idea of stakeholder directors on the board is not alien to countries in the civil-law tradition, such as China, Japan, and Germany, which have worker representation on the supervisory board with varying degrees of voting powers. In China, it is already a statutory requirement that a limited-liability company or a company limited by shares must have a Board of Supervisors, which must have no fewer than three members, and that the Board of Supervisors must include the representatives of the shareholders and an appropriate ratio of representatives of the company's staff and workers, in which the ratio of the staff and workers' representatives must not be lower than one-third. ${ }^{38}$ Similarly, a limited-liability company must also have a board of directors of three to 13 members ${ }^{39}$ and, if it is invested in and established by two or more state-owned enterprises or two or more other state-owned investment entities, the members of the board of directors must include representatives of the staff and workers of the company. ${ }^{40}$ In other limited-liability companies, the members of the board of directors may include representatives of the staff and workers

36. Goo \& Klingler, supra note 15 , p. 195.

37. See e.g. Hkex.com (2013); Accaglobal.com (2015); Robeco.com (2015).

38. Articles 51 and 117, respectively, Company Law (revised in 2013). A limited-liability company with comparatively few shareholders and comparatively small in scale may have one to two supervisors instead of a Board of Supervisors.

39. Company Law (2013), Art. 44.

40. Ibid. 
of the company. ${ }^{41}$ A wholly state-owned company must have a board of directors, whose members must include representatives of the staff and workers. ${ }^{42}$ A company limited by shares must have a board of directors of five to 19 members, which may include representatives of the staff and workers of the company. ${ }^{43}$ Thus, the idea of having directors representing different stakeholders including workers would just be an extension of the present system in China to include other stakeholders on the board.

\subsection{Stakeholder Directors to Owe Duties to Stakeholders with an Overriding Duty to Act for the Interests of the Company and "Company" Should Mean Shareholders and Stakeholders}

Since stakeholder directors are to represent stakeholder interests, they should owe a duty to the stakeholders, instead of shareholders (as is currently the case). Stakeholder directors should owe a duty to their constituencies to act diligently for the interests and benefit of their constituencies. This will solve the current problem of directors not being accountable to stakeholders.

However, stakeholder directors representing one type of stakeholder (e.g. worker) cannot act solely for the interests of that type of stakeholder, as the company does not consist merely of that type of stakeholder. The company, in its original idea, consists of shareholders and other stakeholders in the society in which it operates. Thus, the duty that stakeholder directors owe to their constituencies must be subject to the overriding duty to act bona fide in the interests of the company (which must mean shareholders and other stakeholders). The interests of the company as a whole would be the combined interests of all stakeholders (including shareholders), and not the traditional view of the interests of shareholders; directors would not face conflict of interests as would be the case under the enlightened shareholder value approach where some directors may find it difficult to balance the interests of the various stakeholders and shareholders. The balancing would be done by the votes cast by each director. In other words, each director would be able to act for the interests of the stakeholders he represents so long as he acts bona fide in the interests of the company as a whole. The overriding duty to act bona fide in the interests of the company as a whole means that each director must act in a spirit of co-operation with other stakeholder directors whilst advocating and pursuing the interests for their constituency. It means that he must not act deliberately to frustrate the purpose, function, and operation of the company.

The decision of the company would be made by all stakeholder directors representing the different constituencies including shareholder interests through voting. Through their directors, stakeholders would have better access to corporate information regarding major corporate decisions, would be able to take part in the debate, may raise questions about the proposed corporate decision, could influence the outcome of the decision, and ultimately vote to approve or reject the proposed resolution. ${ }^{44}$ Stakeholder directors, including shareholder directors, would have to make various compromises or sacrifices in order to get

41. See ibid. (limited-liability company). A limited-liability company with comparatively few shareholders or comparatively small in scale may have one executive director instead of a board of directors (Art. 50). The executive director may concurrently serve as the manager of the company.

42. Company Law (2013), Art. 67.

43. Company Law (2013), Art. 108.

44. Goo \& Klingler, supra note 15 , p. 195. 
what their constituencies demand, depending on the dynamics of the board and the interests of other stakeholders. This would lead to better corporate decisions in terms of serving the interests of all stakeholders including shareholders. ${ }^{45}$ Thus, companies may have to agree to pay workers more, or pollute the environment less, or make safer and better products, resulting in less profit for the shareholders in order to get the support of various stakeholders for a particular decision. Workers may have to accept lower pay than they demand or promise to increase efficiency and output in order to keep their jobs. ${ }^{46}$ Environmental directors may have to accept a less stringent standard (but still meeting standards required by law or regulation) in pollutant discharge to get the support of other stakeholders or shareholder directors. ${ }^{47}$ The decision that results from this process would not meet the initial demand by all stakeholders, but would be the best possible decision in the circumstances and represent the best interests of the company and society. All costs of production or operation of the company would be internalized as much as possible and societal resources would be allocated efficiently by the invisible hand in the boardroom.

This idea of stakeholder participation in the corporate decision-making process is informed by economic principles and is not new. Nader, Green, and Seligman proposed it in the 1970s. ${ }^{48}$ However, at the time, the American Bar Association (ABA), the Conference Board, and the Business Roundtable preferred Mel Eisenberg's idea of a monitoring board but in the end turned it into a protective shell for directors. ${ }^{49}$ Nader et al.'s idea of a stakeholder representative board was never considered seriously, as the endorsement of Eisenberg's monitoring board by the ABA Guidebook, the Conference Board Report and the Business Roundtable completely rejected the possibility of its being adopted, ${ }^{50}$ or the idea of constituency directors or co-determination. ${ }^{51}$ Mitchell lamented that the contemporary board is a defensive institution that was not designed to serve the goal of ensuring the responsible and efficient management of the large public corporation, and argued that reformers who truly believe in boards must reconceptualize the very purpose of a board before engaging in meaningful reform. ${ }^{52}$ Whilst he does not offer any concrete solution, he does point out the possibility of having "some other substantive modification of the role of the board and, with it, its composition." 53 As companies continue to externalize costs, it may be time to revisit the idea of a stakeholder board to improve the composition of the board.

Co-determination between shareholders and workers in the supervisory board practised for years in Germany is one version of a stakeholder board, consisting of only the shareholder directors and worker representatives. And it is confined to a supervisory board, not a board of directors. But it is a model with reference value to the idea of having stakeholder directors in the board of directors in a unitary board system proposed here. Whilst it is acknowledged that workers in Germany rarely succeeded in vetoing a board resolution, their interest is clearly taken

\footnotetext{
45. Ibid.

46. Ibid.

47. Ibid

48. Nader et al., supra note 19, p. 125; see also Tamethecorporation.org (2007).

49. Mitchell (2010), pp. 31-4.

50. Ibid., pp. 35-47.

51. Business Roundtable (1978), pp. 2105-6.

52. Mitchell, supra note 49, p. 59.

53. Ibid., p. 61, emphasis added.
} 
into account by the board. ${ }^{54}$ Similarly, in Japan, although workers do not formally have a say in the board, their interests are often looked after by directors who are almost always appointed from the rank of workers and therefore owe allegiance to the workers. ${ }^{55}$ In Germany and Japan, another stakeholder, namely banks, as creditors, are also heavily involved in the corporate decision-making process as shareholders of the company, and are keen to protect their own interests. ${ }^{56}$ Thus, workers' and creditors' interests are factored into the decision of a German corporation by having workers' representatives and creditors on the supervisory board, whilst workers' interests in Japanese corporations are taken care of by directors. In China, workers are represented on both the Board of Supervisors and the board of directors.

\subsection{Problems and Difficulties}

The idea of a stakeholder board can be difficult to sell, as it could slow down the decisionmaking process and make the process contentious. ${ }^{57}$ Hansmann and Kraakman argued that the stakeholder model would tend to lead to inefficient decisions, paralysis, or weak boards, which create additional costs. ${ }^{58}$ Bainbridge was very sceptical about the efficiency of multiple constituencies. ${ }^{59}$ Others worried about the loss of confidentiality, ${ }^{60}$ and the divergence of employee and shareholder interests, which not only impedes consensus, but also permits management to pursue its own self-interest, as well as the indifference of workers to corporate decisions. ${ }^{61}$

However, there are already some companies that have various forms of stakeholder representation on the board in Europe. Further research and observation of how such boards operate in practice are needed. Through such a case-study, ways to overcome these problems can be developed. In the meantime, let me address some of the problems as follows.

\subsubsection{Concern that a Stakeholder Board Would Lead to an Inefficient Decision-Making Process}

It is obvious that stakeholder directors' participation in the board may cause the board to take longer to make a decision that would be the best possible decision to meet the interests of all stakeholders in the circumstances, and the process could be contentious. However, this does not mean that the process is "inefficient" just because it would take longer. If it would lead to a better decision, it is worth taking a little longer. A faster decision (hence more "efficient" process) that only benefits the shareholders and externalizes the costs ${ }^{62}$ is not efficient and is bad for society.

Furthermore, there are other advantages to be gained when stakeholders are involved in the decision-making process. The company can also exert a higher degree of control through

54. Goo \& Klingler, supra note 15, p. 196

55. Ibid.

56. Ibid.

57. Ibid., p. 201.

58. Hansmann \& Kraakman (2001), p. 445.

59. See Bainbridge (2008); Bainbridge (1996).

60. See Ottervanger \& Pais (1981), pp. 393-410.

61. Bainbridge (2008), supra note 59, pp. 45-9; Bainbridge (1996), supra note 59, pp. 657-730; see also Roe (1999), p. 194.

62. See Blair (2003), p. 57. 
trade-offs in the board. For example, the company can get the suppliers to agree to comply with the company's code of conduct, such as prohibiting child labour, in return for meeting the demand of the suppliers. Thus, if the practical challenges relating to the mechanics of such a board can be overcome, such a board could create a win-win situation for both the stakeholders and the shareholders, and therefore contribute to societal efficiency as a whole. ${ }^{63}$

One possibility ${ }^{64}$ is to restrict stakeholder directors' participation in the board to important matters or when the interests of stakeholders are affected as in the German and Dutch systems where, although the management board is responsible for administration generally, for "certain types of business," or businesses that are of "fundamental importance,"65 such as "measures that fundamentally change the financial position of the company and the results of its operations and its cash flows," $" 66$ the consent of the supervisory board is required. ${ }^{67}$

Matters that are purely commercial or administrative in nature would not require stakeholder directors' participation on the board. The critical question is where to draw the line. The German works council is given rights of co-determination in social, ${ }^{68}$ commercial, ${ }^{69}$ and personnel matters. ${ }^{70}$ Similarly, the Dutch works council can disapprove changes of certain employment conditions, ${ }^{71}$ can render advice on decisions concerning significant changes in business, ${ }^{72}$ and has the right to receive information on corporate decisions. ${ }^{73}$ Thus, detailed rules can be designed to give each constituency a different degree of co-determination rights on different issues.

\subsubsection{Ratio of Shareholder and Stakeholder Representation}

How do we decide the ratio of shareholder and stakeholder representation on the board? Should we allocate the percentage of the board representation equally among shareholder and stakeholder directors or should one group have a dominant vote?

Giving shareholder directors and stakeholder directors equal votes in the board recognizes the equal importance between a company's social responsibility and its profit maximization. In the event of a tie, a solution is to appoint an independent chairman with the power to break the tie. The independent chairman could be jointly appointed by shareholder and stakeholder directors. Of course, in practice, it may be difficult to find truly independent

63. Goo \& Klingler, supra note 15 , p. 202.

64. Ibid.

65. German Corporate Governance Code (2010), § 3.3 .

66. Ibid.

67. German Stock Corporation Act (2011), § 111, s. 4; Hempel \& Wiemken (2006), p. 26. The Dutch Civil Code lists financial matters such as issuance of shares, major investments, filing for bankruptcy, termination of the employment of a substantial number of employees, or a drastic change in employment conditions as major decisions; see Dutch Civil Code, Art. 2: 274, § 1 .

68. E.g. employment conditions including working hours, extra work, holiday regulations, and safety measures; see German Works Constitution Act (2009), § 87, s. 1.

69. E.g. closure, transfer, or consolidation of the business: see German Works Constitution Act (2009), §§ $111 \mathrm{ff}$.

70. E.g. recruitments or relocations; the works council can only refuse its approval according to a certain catalogue of reasons, e.g. when measures infringe the law or disadvantage other employees; see German Works Constitution Act (2009), § 99, ss. 1, 2. See Goo \& Klingler, supra note 15, p. 203.

71. Dutch Works Council Act (1971), Art. 27.

72. Ibid., Art. 25.

73. Ibid., Art. 31. See Goo \& Klingler, supra note 15, p. 203. 
directors or chairmen. ${ }^{74}$ The management is likely to appoint people who are sympathetic to its policy. So another option is to refer a tie to an arbitrator. ${ }^{75}$ In the German system, employee representatives and shareholder representatives have equal votes, but the chairman who is a shareholder representative has a casting vote when there is a tie, so shareholders have more weight in the decision-making process.

\subsubsection{Appointment of Constituency Representatives}

Another challenge relates to the representatives of the stakeholder constituencies. There are at least six stakeholder groups that may have interests in the company's operation. Members of the constituencies of employees, suppliers, creditors, and shareholders are more easily defined, identified, and are limited. They can appoint their own representatives to represent their interests on the board. Consumers and the environment are more difficult.

For the environment constituency, one could treat the local community in which the company is operating as the stakeholder. This could include the areas and people that would be directly affected by an environmental accident and would eventually claim for damages. ${ }^{76}$ However, the number is difficult to define and identify to ask them to appoint their representatives. One possibility is to let a national environmental protection agency and, in the case of a multinational corporation, an international environmental agency such as Greenpeace represent or appoint people to represent this constituency.

Similarly, for the consumer constituency, as it is difficult to define and identify the number of consumers likely to be affected by the company's product or services, one could again let a national or international consumer protection agency such as the nonprofit organization Consumer International represent or appoint people to represent the consumers' interests. ${ }^{77}$

\subsubsection{Appropriate Target Companies}

The idea of stakeholder directors is to ensure that the board takes into account the interests of stakeholders. Thus, for companies that already respect and take into account the interests of all stakeholders in their operation, this idea could be optional. But, for companies that frequently make profits at the expense of other stakeholders, this should be compulsory. This will also have a self-disciplinary effect on companies that do not want to adopt this idea.

Furthermore, whilst the idea is not limited to any type or size of company, as a pilot scheme, one could start with multinational corporations that have failed to respect the interests of stakeholders, such as those that have been in the media or involved in court proceedings because of human rights' violations or environmental pollution. ${ }^{78}$ Such corporations have a bigger impact on the society due to their substantial turnovers. They could also serve as role models for smaller local companies. Stakeholder boards will help them to internalize costs instead of outsourcing externalities to other weaker countries. ${ }^{79}$

74. See Cohen et al. (2012); Sturms (1999); Higgs (2003); Hong Kong Institute of Chartered Secretaries (2006).

75. See Goo \& Klingler, supra note 15, p. 206.

76. See BP Oil Spill Class Action Claim Settlement from March 2012, Economic Zone Maps \& Real Property Settlement Maps.

77. Goo \& Klingler, supra note 15 , pp. 206-7.

78. E.g. BP, Shell, Nike, or Apple; see for further examples Werther \& Chandler (2010), p. 281.

79. Goo \& Klingler, supra note 15, p. 207. 


\subsubsection{Level and Degree of Implementation}

For stakeholder boards to be successfully implemented, a concerted effort and co-operation at the international level are necessary to ensure that multinational corporations cannot migrate to a jurisdiction that does not have such a board. Guidelines at the international level also ensure a certain degree of harmonization. ${ }^{80}$

As mentioned, at this stage, this idea of stakeholder directors should be voluntary, except multinational corporations that have records of violation. This is in line with the current practice in corporate social responsibility (CSR) that allows voluntary compliance. Even though many authors have argued for mandatory rules in CSR and some countries have already taken legislative action, ${ }^{81}$ it would appear that introducing stakeholder boards on a voluntary basis at this stage would inspire more supporters. Experience has shown that successful ideas first adopted internationally on a voluntary basis have later become part of national laws. ${ }^{82}$

\subsubsection{Who Can Take the Lead to Introduce the Idea?}

As the idea should be implemented at the international level with international co-operation, an international organization would be the most appropriate organization to take the lead. While several organizations are active in the field of business and human rights, ${ }^{83}$ the $\mathrm{UN}$ and the OECD seem to be most appropriate for the implementation of the proposed stakeholder board, as they have a large number of members, ${ }^{84}$ the OECD having developed the "OECD Guidelines for Multinational Enterprises" 85 and the High Commissioner for Human Rights having developed the Guiding Principles on Business and Human Rights ${ }^{86}$ and also responsible for the establishment of the UN Global Compact. They already possess the necessary expertise and authority, and would therefore appear to be the most suitable bodies to establish guidelines for the implementation of a stakeholder board for multinational corporations. ${ }^{87}$

\section{CONCLUSION}

Whilst market is arguably the best way to allocate resources efficiently, and corporations exist to reduce transaction costs, the Anglo-American corporate law has allowed many costs of a corporate operation to be externalized, leading to inefficient allocation of resources for society as a whole and human rights abuses. In view of the growing demand of the international community for companies to take social responsibility for their business activities and their impact on the environment and society as a whole, new concepts that allow costs of a company's operation to be internalized need to be developed. A stakeholder representative

80. Ibid., p. 208.

81. Bendall (2004), pp. 14-18; Gayo (2012); Kerr et al. (2009), p. 30; Crawford \& Williams (2010), pp. 512-26; Price (2010), p. 19; Ward (2003); Wettstein \& Waddock (2005), pp. 304-20.

82. For example, the Basel Accords. Goo \& Klingler, supra note 15, p. 208.

83. The International Labor Organisation, the World Trade Organization (WTO), the Global Reporting Initiative, or Ceres-both nonprofit organizations that promote economic sustainability.

84. Goo \& Klingler, supra note 15 , p. 209.

85. Oecd.org (2011).

86. Ohchr.org (2011).

87. Goo \& Klingler, supra note 15 , p. 209. 
board is one way towards achieving this goal. Of course, there are difficult operational issues about the composition of the board and the power-sharing arrangement between different stakeholders and shareholders, but such difficulties are not insurmountable.

As a pilot scheme, to test the effectiveness and practicalities of such a board, we could start with multinational corporations that have a history of corporate abuse. For all other companies, such a board could be adopted on a voluntary basis. Such a board, if successfully implemented, would be an example of how economic principles inform better law reform.

\section{REFERENCES}

Accaglobal.com (2015) "Diversifying the Board-a Step Towards Better Governance," http:// www.accaglobal.com/ie/en/student/exam-support-resources/professional-exams-study-resources/p1/ technical-articles/diversifying-the-board-a-step-towards-better-governance.html (accessed 7 May 2017).

Ashton, Douglas (2012) “Revisiting Dual-Class Stock.” 68 St. John's Law Review 863-960.

Bainbridge, Stephen M. (1996) "Participatory Management within a Theory of the Firm." 21 Journal of Corporation Law 1-105.

Bainbridge, Stephen M. (2008) The New Corporate Governance in Theory and Practice, New York: Oxford University Press.

Bendall, Jem (2004) "Barricades and Boardrooms: A Contemporary History of the Corporate Accountability Movement." 13 Technology Business and Society Programme Paper 14-18.

Blair, Margaret M. (2003) "Shareholder Value, Corporate Governance, and Corporate Performance: A Post-Enron Reassessment of the Conventional Wisdom," in P.K. Cornelius \& B. Kogut, eds., Corporate Governance and Capital Flows in a Global Economy, New York: Oxford University Press, 53-132.

Boyle, Anthony J., \& John Birds (1995) Boyle \& Birds Company Law, 3rd edn, Bristol: Jordan.

Business Roundtable (1978) "The Role and Composition of the Board of Directors of the Large Publicly Owned Corporation.” 33 Business Lawyer 2083-2113.

Cheffins, Brian R. (1997) Company Law: Theory, Structure and Operation, Oxford: Clarendon Press.

Coase, Ronald H. (1937) "The Nature of the Firm." 4 Economica, New Series 386-405.

Coase, Ronald H. (1960) "The Problem of Social Cost." 3 The Journal of Law and Economics 1-44.

Cohen, Lauren, Andrea Frazzini, \& Christopher J. Malloy (2012) "Hiring Cheerleaders: Board Appointments of 'Independent' Directors." 58 Management Science 1-20.

Crawford, Elise Perrault, \& Cynthia Clark Williams (2010) "Should Corporate Social Reporting be Voluntary or Mandatory? Evidence from the Banking Sector in France and the United States." 10 Corporate Governance 512-26.

Farrar, John F. (1991) Farrar's Company Law, 3rd edn, London: Butterworths.

Friedman, Milton (1970) "The Social Responsibility of Business Is to Increase Its Profits," The New York Times Magazine, 13 September.

Gayo, Sabela (2012) "Mandatory and Voluntary Corporate Social Responsibility Policy Debates in Indonesia" Presented AT Chiang Mai: International Conference on International Relations and Development, ICIRD, 26 July 2012.

Goo, Say H. (2015) Should Weighted Voting Right Structure Be Allowed in an IFC: The Hong Kong Story" Presented at 4th Global Conference on Economic Geography 2015, Oxford University, 19-21 August 2015.

Goo, Say H. (2017) “The Legislative Policy of Real Estate Tax" Presented at 2017 Real Estate Taxation Law and Policy Symposium (Taiwan Law Foundation), 4-5 March 2017.

Goo, Say H., \& Désirée Klingler (2014) "The Limit of Directors' Duties in Fostering Corporate Respects for Human Rights and Proposed Stakeholder Board," in A. Paolini, ed., Research Handbook on Directors' Duties, Cheltenham: Edward Elgar, 185-210. 
Hansmann, Henry, \& Reinier Kraakman (2001) "The End of History for Corporate Law." 89 Georgetown Law Journal 439.

Hempel, Jan M., \& Florian Wiemken (2006) Managerhaftung im Wandel: Sarbanes-Oxley und Corporate Governance in Deutschland, Bremen: Salzwasser-Verlag.

Higgs, Derek (2003) Review of the Role and Effectiveness of Non-Executive Directors, London: Stationery Office.

Hkex.com (2013) "Hong Kong Exchanges and Clearing Limited ('Company') Board Diversity Policy," http://www.hkex.com.hk/eng/exchange/corpgov/documents/board\%20diversity\%20policy.pdf (accessed 7 May 2017).

Hong Kong Institute of Chartered Secretaries (2006) “The Duties and Responsibilities of Independent Non-Executive Directors of Hong Kong Main Board Listed Companies." 2 HKICS Publication $1-55$.

Kerr, Michael, Richard Janda, \& Chip Pitts (2009) Corporate Social Responsibility: A Legal Analysis, Markham, Ontario: LexisNexis.

Mitchell, Lawrence E. (2010) "The Trouble with Boards," in F.S. Kieff \& T.A. Paredes, eds., Perspectives on Corporate Governance, New York: Cambridge University Press, 17-61.

Nader, Ralph, Mark Green, \& Joel Seligman (1976) Taming the Giant Corporations, New York: Norton.

Oecd.org (2011) “OECD Guidelines for Multinational Enterprises 2011,” https://www.oecd.org/ corporate/mne/48004323.pdf (accessed 20 may 2017).

Ohchr.org (2011) "Guiding Principles on Business and Human Rights: Implementing the United Nations 'Protect, Respect, Remedy' Framework," http://www.ohchr.org/Documents/Publications/ GuidingPrinciplesBusinessHR_EN.pdf (accessed 20 May 2017).

Ottervanger, Tom R., \& Ralph M. Pais (1981) "Employee Participation in Corporate Decision Making: The Dutch Model." 15 International Lawyer 194.

Parkinson, John E. (1993) Corporate Power and Accountability, Oxford: Clarendon Press.

Posner, Richard A. (1974-75) "The Economic Approach to Law." 53 Texas Law Review 757.

Price, Tom (2010) "Corporate Social Responsibility: Is Good Citizenship Good for the Bottom Line?" in CQ Researcher, ed., Issues for Debate in Corporate Social Responsibility, Selections from CQ Researcher, Los Angeles: Sage Publications, 1-24.

Robeco.com (2015) "Do Companies with Diversified Boards Have Higher Stock Returns?" http:// www.robeco.com/images/do-companies-with-diversified-boards-have-higher-stock-returns-april2015.pdf (accessed 7 May 2017).

Roe, Mark J. (1999) "Codetermination and German Securities Markets," in M.M. Blair \& M.J. Roe, eds., Employees and Corporate Governance, Washington DC: Brookings Institution Press, 194-205.

Sturms, David A. (1999) "Enhancing the Effectiveness of Independent Directors: Is the System Broken, Creaking, or Working?" 1 Villanova Journal of Law and Investment Management 103-41.

Tamethecorporation.org (2007) "Taming The Giant Corporation: A National Conference on Corporate Accountability," http://www.tamethecorporation.org (accessed 7 May 2017).

Ward, Halina (2003) "Legal Issues in Corporate Citizenship." International Institute for Environment and Development, 1-44, http://pubs.iied.org/pdfs/16000IIED.pdf (accessed 20 May 2017).

Werther, William, \& David Chandler (2010) Strategic Corporate Social Responsibility, Stakeholders in a Global Environment, Los Angeles: Sage Publications.

Wettstein, Florian, \& Sandra Waddock (2005) "Voluntary or Mandatory: That Is (Not) the Question, Linking Corporate Citizenship to Human Rights Obligations for Business." 6 Zeitschrift für Wirtschafts-und Unternehmensethik 304-20. 